\title{
Exploitation of plantain (Musa spp.) plantations as an agrotourist element
}

\author{
Bonilla-Gutiérrez, Esthefanía $^{1}$; Gómez-Merino, Fernando Garlos ${ }^{1 *}$;rejo-Téllez, Libia Iris $^{2}$; \\ García-Albarado, J. Gruz ${ }^{1}$; Hidalgo-Contreras, Juan Valente ${ }^{1 *}$ \\ 1 Colegio de Postgraduados Campus Córdoba. Carretera Federal Córdoba-Veracruz km 348, Manuel León, \\ Amatlán de los Reyes, Veracruz, Mexico. C. P. 94953. \\ 2 Colegio de Postgraduados Campus Montecillo. Carretera México-Texcoco km 36.5, Montecillo, Texcoco, \\ Estado de México, Mexico. C. P. 56230. \\ * Correspondence: fernandg@colpos.mx and jvhidalgo@colpos.mx
}

Gitation: Bonilla-Gutiérrez, E., Gómez-Merino, F. C., Trejo-Téllez, L. I., García-Albarado, J. C., \& HidalgoContreras, J. V. (2021). Exploitation of plantain (Musa spp.) plantations as an agrotourist element. Agro Productividad. https://doi.org/10.32854/agrop. v14i9.1774

Editor in Ghief: Dr. Jorge Cadena Iñiguez

Received: March 23, 2021. Accepted: August 12, 2021. Published on-line: October 14, 2021

This work is licensed under a Creative Commons Attribution-NonCommercial 4.0 International license.

\begin{abstract}
Objective: To analyze the processes and alternative uses that plantain cultivation may have, in addition to places with tourist potential in the town Monte Salas, municipality of Fortín de las Flores, Veracruz, Mexico. Design/Methodology/Approach: A review of the space of the study area was performed, as well as an anthropological analysis, description of the process of the plantain leaf used to prepare local food, commercial analysis, development of a sustainable product, and a research stay in Colombia.

Results: In Monte Salas, Fortín de las Flores, Veracruz, Mexico, plantain cultivation is regarded as an outstanding element of the landscape, together with the process of leaf roast production as a value-adding strategy to generate biodegradable co-products. Through the dissemination of audiovisual capsules on social networks, places with tourist potential were made known and together with the implementation of the offer of biodegradable co-products, it was demonstrated that plantain leaf can be used alternately.

Study Limitations/Implications: Due to the SARS-GoV-2 (COVID-19) coronavirus pandemic, the dissemination of our findings and products were restricted.

Conclusions: Novel biodegradable products can be manufactured from plantain leaves, which created a special interest of local tourists to visit Monte Salas and enjoy the agrosystemic landscape.
\end{abstract}

Keywords: agrosystemic, landscape, co-product, biodegradable.

\section{INTRODUCTION}

Bananas and plantains belong to the Musa genus within the Musaceae family, and are native to South Asia. Within this family there are two species of current commercial importance: Musa cavendish, which includes bananas, and Musa $\times$ paradisiaca, which includes plantains (Díaz Arango et al., 2015). In addition, there are numerous interspecific hybrids that are easily catalogued as Musa spp. From Asia, this genus reached the Canary Islands in the 15th century and was later introduced to the American continent. Currently, this crop has spread to many regions of Central and South America, constituting the basis of the diet and of the economy of many tropical regions (Secretaría de Agricultura y Desarrollo Rural, 2020). 
In addition to its nutritional importance, this crop is an important source of employment and income in developing countries. As an agrifood power, Mexico produces a variety of crops for both domestic consumption and export, including bananas and plantains (Villalobos-Arámbula, 2019). The main banana and plantain producing states are Chiapas with 35\% of national production; Tabasco with 22\%; Veracruz with 19\%; and Michoacán and Colima with 7\% each (Secretaría de Agricultura y Desarrollo Rural, 2020).

In addition to the fruit, this crop produces other products and by-products, such as pseudostems, leaves and veins. Furthermore, banana agroecosystems can be a tourist attraction for visitors. As a landscape element, banana plantations tend to enrich the value of sites by incorporating a diversity of species within the Musa genus, as well as other plant species, both cultivated and wild. This plant diversity also results in a greater flow of animals such as reptiles, birds and mammals, among others.

In order to have a regional and international view of the potential uses of plantain in agro-ecotourism perspectives, a study and liaison stay was conducted in the community of San Rafael, Antioquia, Colombia. This stay made it possible to record and to analyze various processes within the management and utilization of banana, and its potential inclusion as an attraction in agro-ecotourism projects, applicable to the reality of Monte Salas in Mexico.

\section{MATERIALS AND METHODS}

The first part of the study consisted of analyzing banana cultivation from a visual perspective, taking agroecosystemic landscapes as a tourist attraction. This section was divided into four stages:

Understanding the space through landscape ecology. In order to understand the study of the landscape, the basic concepts that integrate it and the critical path of analysis were first defined. Subsequently, the way in which elements of the study area interact with each other was studied, that is, analyzing how agriculture is the predominant activity in the area and how banana plantations are the second most important crop. The relationship that exists among banana producers in Monte Salas, Fortín de las Flores, Veracruz, Mexico (Coordinates: 18 54' 16" N, 96 59' 21" W, 1400 m.a.s.l.) was established with this approach (CEIEG, 2020) (CEIEG, 2020).

The understanding stage was used to determine how widespread the crop is in the area. For this purpose, photographs were taken from a high point, according to the criteria of landscape ecology described by Forman and Godron (2009), whose structure of a landscape consists of matrices, patches and corridors (Vila et al., 2019).

Anthropological analysis. Another important aspect for the analysis of this study was the anthropological explanation of how the crop emerged in this region. Based on documentary research, historical processes were compiled by searching for maps and written documents containing information about activities in local, state and national archives. This section described how banana cultivation was introduced in the High Mountains Region of Veracruz (Región de las Altas Montañas de Veracruz, RAMV) and how it eventually became more important than coffee cultivation (Coffea arabica and C. canephora), becoming the main economic activity in different localities of the region (Chávez-Hita and Florescano, 2013). 
Description of the production process. In the third stage, the banana leaf production process was described, for which velillo cutters (local name for the plantain leaf) were identified, as well as the drivers who transport velillo to Mexico City. With the use of audiovisual tools, the process of roasting the leaf for use in the preparation of tamales and other regional foods was documented.

Commercial analysis. During field work, the profitability of banana leaf cutting for the main cutters in the area was investigated. In addition, a more integral and novel use of the plant's products was proposed, in addition to the production of fruits and velillo. This new approach could increase the flow of tourists to the area, and the use of audiovisual tools could enhance its diffusion.

Alternative uses of the plantain crop. Based on the field work with the cutters, it was determined that after the fruit, the leaf is the main usable and marketable product. Tests were carried out to find a different use for the leaf, and it was concluded that the optimal use would be in the manufacture of disposable utensils for serving food. In order to have a broader knowledge about plantain cultivation, an internship was carried out in San Rafael, Antioquia, Colombia, place where more practical knowledge was generated about the use of the banana leaf in a sustainable and applicable way for sustainable tourism. To conclude the research and evaluate whether these product alternatives were viable, trials were conducted to create a biodegradable product. For this purpose, a prototype of a plate was made with the leaf and starch of cassava (Manihot esculenta), making it resistant to liquids without leaks, achieving a product that can be industrialized. This prototype developed in Colombia was tested in the town of Monte Salas, Mexico.

\section{RESULTS AND DISGUSSION}

Understanding the physical space constitutes the first step in formulating concrete questions about the landscape and its analysis (Thiébaut, 2017). To describe the landscape it is important to understand that the territory is understood as the space appropriated by a social group to ensure its reproduction and the satisfaction of its vital needs, which can be material and symbolic. It can be considered a refuge zone, a means of subsistence, a source of resources, and also a landscape, a privileged ecological environment, an object of emotional attachment, a homeland, and a geographic symbol. The result of the transformation of the environment by agricultural activity constitutes a key element of landscapes in the rural environment, and hence geography is considered as a science of the landscape, of the territory organized by human societies, and of the relationships of human beings with the environment (Ramírez and López, 2015).

To begin with the first part of the analysis process, concepts and methods were used framed in landscape ecology, a discipline that deals with planning of landscape and nature (Troll, 2003), and with which units that make up the landscape can be delimited. Thus, we looked for the observation point where there is a panoramic view and an overview of the landscape, taking into account land use, plots, vegetation forms, dominant function of an area, areas where the population is established (Hiernaux and Lindón, 2006), which in this case is the study zone and other neighboring localities. Within this framework, the various crops that represent the locality of Monte Salas were also recorded and analyzed. 
The analysis of banana cultivation in the locality of Monte Salas showed two high altitude perspectives that serve as a contrast between one and the other. From a high point, different patches of the landscape are visible (Figure 1A). This photograph was taken from the Cerro de Santa Lucía Potrerillo, near Monte Blanco, and shows elements of the landscape ecology and its structure. Human settlements the patches and the tropical evergreen mountain forest is the dominant matrix. Both climate and soil in the region are conducive to the cultivation of sugarcane (Saccharum spp. hybrids) (Figure 1B) and bananacoffee polyculture (Figure 1C), which are the basis of the local people's economy.

In the second scale, the association of the banana crop with coffee was observed. This association is the most applied in the study area, due to its fast growth and production of edible fruits. Its main characteristic is the way it is planted, since in addition to coffee, vanilla (Vanilla planifolia), orange (Citrus sinensis), bamboo (Bambusa spp.), avocado (Persea americana), and lemon (Citrus $\times$ limon $)$ can be grown, both for family consumption and for local sale.

In the management of banana plants, growers try to keep them at a low height in order to facilitate harvesting of the leaf and midrib. Depending on the stage of growth, the species cultivated and the time of year, a banana plant can measure from 2 to $6 \mathrm{~m}$ approximately (Licona, 2007).

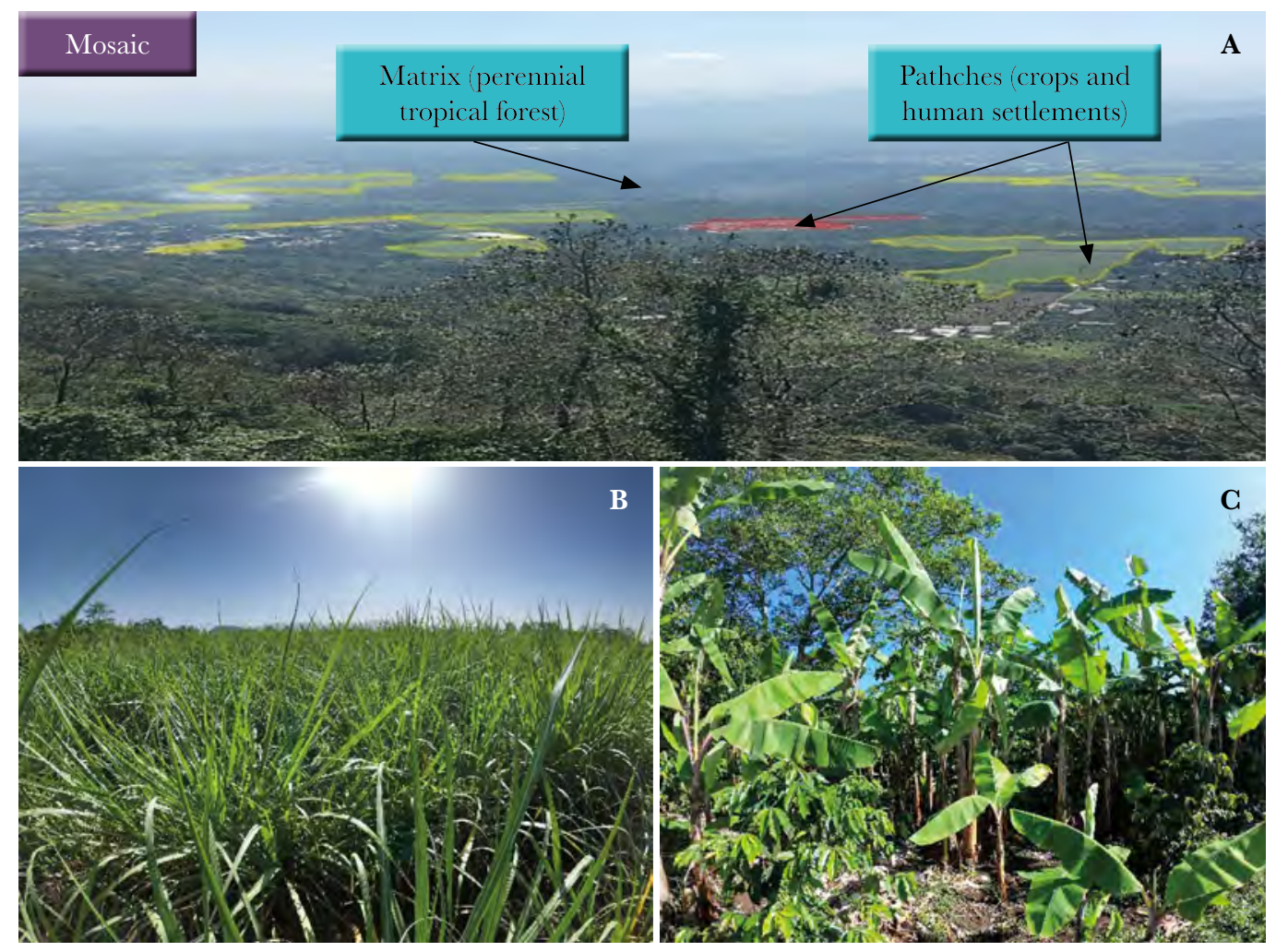

Figure 1. Panoramic picture of the landscape elements of Monte Salas, municipality of Fortín de las Flores, Veracruz, Mexico. The picture was taken from a high mountain in order to appreciate the community and the crops such as sugarcane (Saccharum spp. hybrids) and the polyculture plantain-coffee (Coffea spp.). A) Ecology of the landscape; B) Sugarcane plantations; G) Polyculture plantains-crops. 
The introduction of the banana crop in the High Mountains region came about when landowners became interested in export crops such as sugarcane and coffee. According to Chávez-Hita and Florescano (2013), in 1898 coffee growers in the region were advised not to use banana as a shade crop because it stole moisture from the soil. However, one of the most important haciendas in the locality of Monte Blanco was a pioneer in introducing and adapting the cultivation of coffee in plains and ravines, as well as experimenting with different shades for the harvest. In the decade of 1950 in Monte Salas, a sector of producers opted to maintain their culture based on multiple systems, so since the first half of the decade they began to promote the marketing of banana leaves, locally known as velillo. In addition to the production of edible fruits, there are banana genotypes whose most significant use is the cutting of the leaf to make tamales and wrap other foods produced in the region. Given their Asian origin, according to Pilcher (2001), tamales wrapped in banana leaves began to be made from very early colonial times, mainly in the cultures of the coastal areas of the country. Before colonial times, tamales were made with leaves of species related to the plantain, such as Heliconia, which are native to the American continent.

The elaboration of tamales using banana leaf as a wrapper is an activity considered a driving force of the production system of banana-coffee associations (Susan et al., 2017). Thanks to these systems, it is possible to obtain three agricultural products on the same land: coffee beans, banana fruits and banana leaves. Under this system, leaf cutters earn additional income every two weeks from the sale of leaves; weed growth in the production unit is delayed by the shade and the banana crop residues are composted.

\section{Description of the plantain crop production process}

Currently, banana cultivation represents the second most important commercial activity in the locality of Monte Salas (CEIEG, 2020). In order to intensify this crop, producers have opted to increase the population density within coffee plantations. Thus, more than $80 \%$ of the producers have population densities ranging from 289 to 625 banana vines per hectare with three or four pseudostems each, for a total of 867 and 2500 plants, respectively (Table 1).

This activity is profitable and yields two to three times higher than the specialized system for the production of fruits under the same market conditions of the products are reported. Leaf harvesting is carried out by specialized cutters hired by local leaf collectors.

The process of leaf harvesting and processing consists of four stages. The first stage is leaf cutting, which is carried out by specialized cutters hired by local collectors. The cutting of these leaves has a technique that each cutter must handle perfectly, as they must hold the leaves in the air to prevent them from falling to the ground, getting dirty and damaged (Figure 2A). As they cut, the workers must form rolls of 50 leaves. The second

Table 1. Average production of leaf rolls of plantain (Musa spp.) leaves per pseudostem, hectare and year in Monte Salas, Fortín de las Flores, Veracruz, Mexico.

\begin{tabular}{c|c|c}
\hline Pseudostems per hectare & Rolls per hectare & Rolls per hectare a year \\
\hline 2,300 & 150 & 480 \\
\hline
\end{tabular}


stage of the process consists of passing each leaf sheet directly over fire, an activity carried out by specialized persons in roasting leaves (Figure 2B). The third level of processing is leaf "deveining", which consists of removing the central rib and packaging it (Figure 2C). Finally, the processed leaves are packaged and sold in local markets (Figure 2D).

The commercialization of the leaf or velillo is today the main source of employment in the communities of Monte Salas and Monte Blanco in the municipality of Fortín de las Flores, Veracruz, Mexico. In the town of Monte Salas, Mr. Jacobo Gil Olmedo has formed a microenterprise and has become the main banana leaf collector and marketer. This microenterprise currently has two galleys, each with two wood-fired ovens where the leaves are roasted and then deveined and packaged. A space in his home is used for temporary storage of the velillo rolls.

The cutters are employed by the traders who, through a verbal contract, make agreements with the plantation owners for the cutters to enter their farms to harvest the leaves.
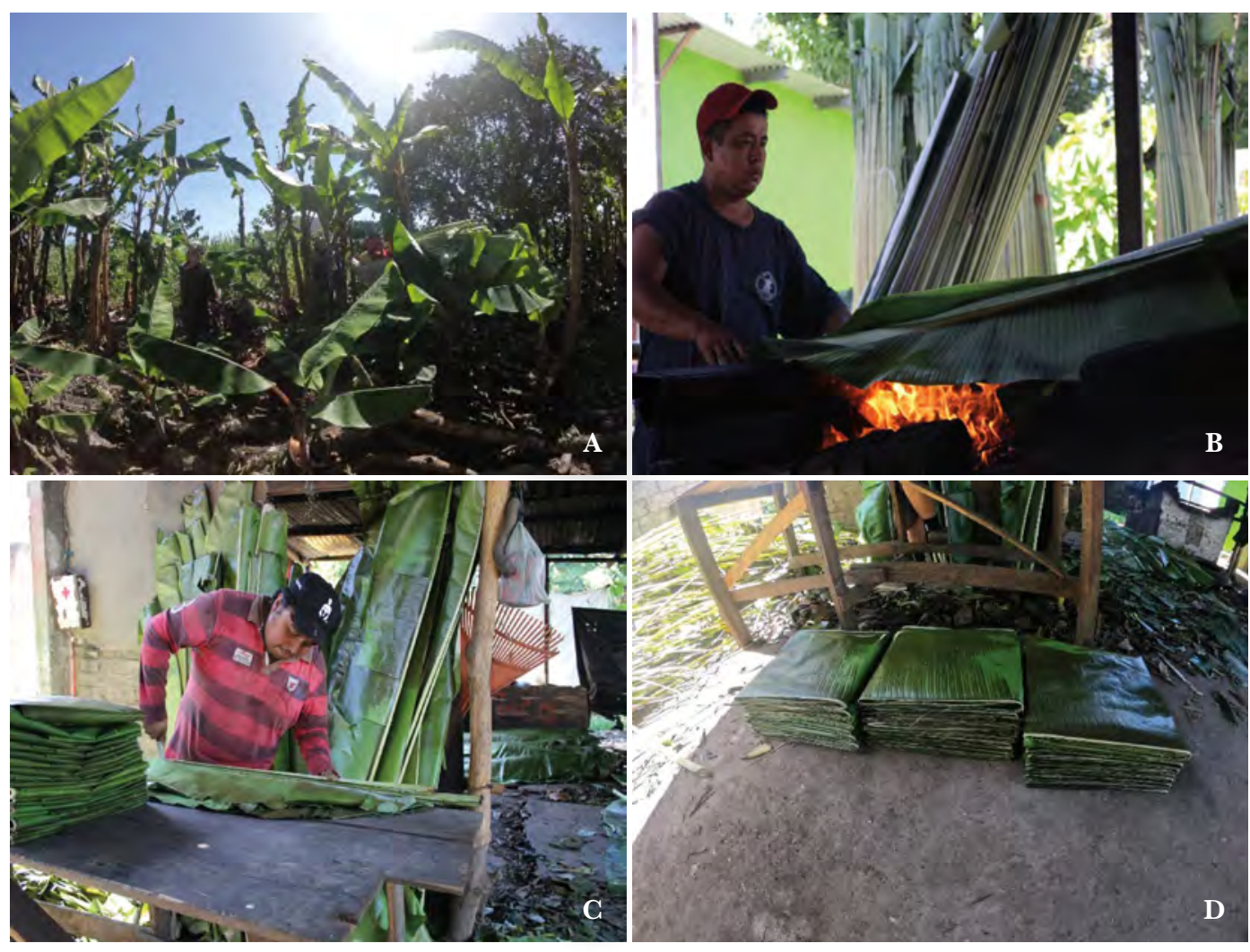

Figure 2. Process of production and manufacturing of plantain (Musa spp.) leaves to prepare tamales and other regional and local foods in Monte Salas, Fortín de las Flores, Veracruz, Mexico. A) Leaf cutting; B) Leaf roasting; C) Leaf deveining (removing the central vain of leaves); D) Packing.

Table 2. Average production of leaf rolls per cutter, price, and cost effectiveness according to the number of rolls estimated during the Summer 2020 (prices in Mexican pesos).

\begin{tabular}{c|c|c|c}
\hline Leaves per toll & Price per roll $\mathbf{( M X \$ )}$ & Rolls per cutter & Cost effectiveness $(\mathbf{M X} \mathbf{\$})$ \\
\hline 50 & $\$ 70$ & 15 & $\$ 1,050$ \\
\hline
\end{tabular}


Growers know that the management of banana residues favors moisture conservation and also reduces the weed population in banana plantations. When decomposed, these agricultural residues become compost that improves soil quality and provides nutrients to plants in production. In the last five years, velillo has been the only product that has risen in price, making it possible to recover production costs and generate constant income throughout the year, since leaf cuts are made biweekly.

Velillo can be sold both raw and roasted. The package of raw velillo has a commercial value of $\$ 130$ pesos per roll and has a shelf life of approximately 8 days after cutting, and the package of roasted velillo is sold for $\$ 150$ pesos, with a shelf life of 6 days, considering average temperature conditions of no more than $24^{\circ} \mathrm{C}$. During periods of high demand that include from October to February, the price of the velillo may rise.

\section{Banana cultivation as an agrotourism attraction}

Promotional videos were made in order to promote the banana production and leaf processing activities, and thus attract tourism to the area under study. To this end, places with tourist potential such as the Tule Lagoon, which belongs to Monte Blanco (Figure 3A) were visited, a trail towards the plantation where there are different tree species, as well as the banana crop (Figure 3B), a trail of palms that make the landscape attractive (Figure 3B), and the river that runs through the entire Monte Salas ravine. Crops such as chayote (Secchium edule), coffee and, of course, banana can be seen along these routes (Figure 3D).
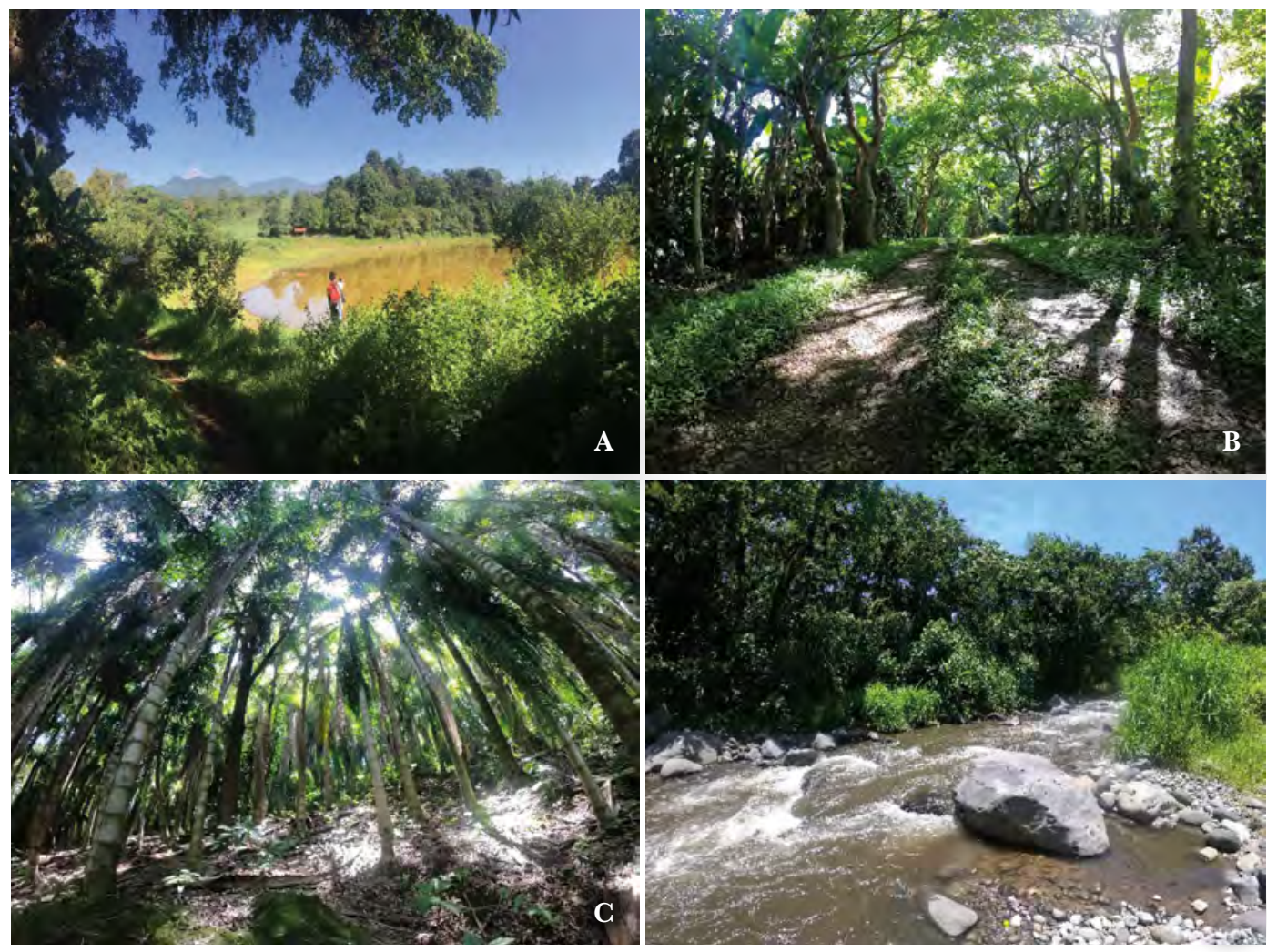

Figure 3. Places with touristic potential in Monte Salas, municipality of Fortín de las Flores, Veracruz, Mexico. 3A) Tule Lagoon. 3B) Road to Tule Lagoon. 3C) Road to Monte Salas river. 3D) Monte Salas river. 


\section{Alternative and sustainable uses of the banana crop}

In addition to the sale of the fruit and leaf, this study raised the possibility of developing some other alternative and sustainable product that could be derived from the same plant. The approach was made taking into consideration that the people of the community themselves could carry out with the raw materials and the tools that were available in the area.

Based on the studies of Mazzeo et al. (2010) on the industrial utilization of banana harvest and post-harvest residues, it was determined that the leaf could be a good element and source of raw material for the elaboration of other useful products in the food service industry. This is because the leaf shows resistance to high temperatures and at the same time sufficient hardness and malleability for handling. Traditionally, the leaf is also used to wrap foods such as cheeses and meats in the region.

In support of this initiative and with the purpose of enriching knowledge on the cultivation and use of banana, a liaison stay in the Republic of Colombia was organized. This decision was made considering that Colombia is one of the main producers and exporters of bananas and plantains in the world (Atlasbig, 2021; FAO, 2021), and that, within that country, the Department of Antioquia concentrates the largest cultivated area with about 70,000 hectares planted with bananas and plantains (Minagricultura, 2020). In order to choose the place where to work, it was necessary to take into account the rural tourism approach, and the municipality of San Rafael in that department was chosen. The Local Tourism Network was contacted to carry out this trip. This network is an organization that, in addition to being the main face of San Rafael in terms of tourism, is also the organization responsible for activities such as seminars, tourism fairs, festivals and the region's festivals. Thanks to them, it was possible to successfully implement the research project within the framework of the research stay.

The activities were carried out in September 2019. First, together with the producers of San Rafael, it was decided to use banana leaves as raw material to produce an alternative product. Subsequently, to coat the leaf, tests were carried out with materials of $100 \%$ natural origin such as propolis from Melipona bees (Apidae family, Meliponini tribe) and cassava starch. Having done these tests, models of biodegradable plates and utensils useful in food service were developed. After roasting the leaves over medium heat, they were made malleable enough to be handled and the starch extracted from the cassava was applied according to the process proposed by Cobana and Antezana (2007) (Figure 4A). To shape the leaves, they are placed in an aluminum mold in the shape of a plate (Figure 4B). This mold is placed in the fire at a temperature of approximately $120^{\circ} \mathrm{C}$ and a pressure of $60 \mathrm{~kg}$. The final product obtained is a $100 \%$ biodegradable sheet made of banana leaf and covered with cassava starch, subjected to temperature and pressure (Figure 4G).

After showing the process of elaboration of the biodegradable dish, the second Tourism Fair of the Province of Water, Forests and Tourism was held in San Rafael. We participated as exhibitors on the first day of the fair, where products made from banana leaves were shown, as well as a brochure explaining how to make them and the benefits of creating ecological alternatives that help the environment. On the second day of the fair, we 

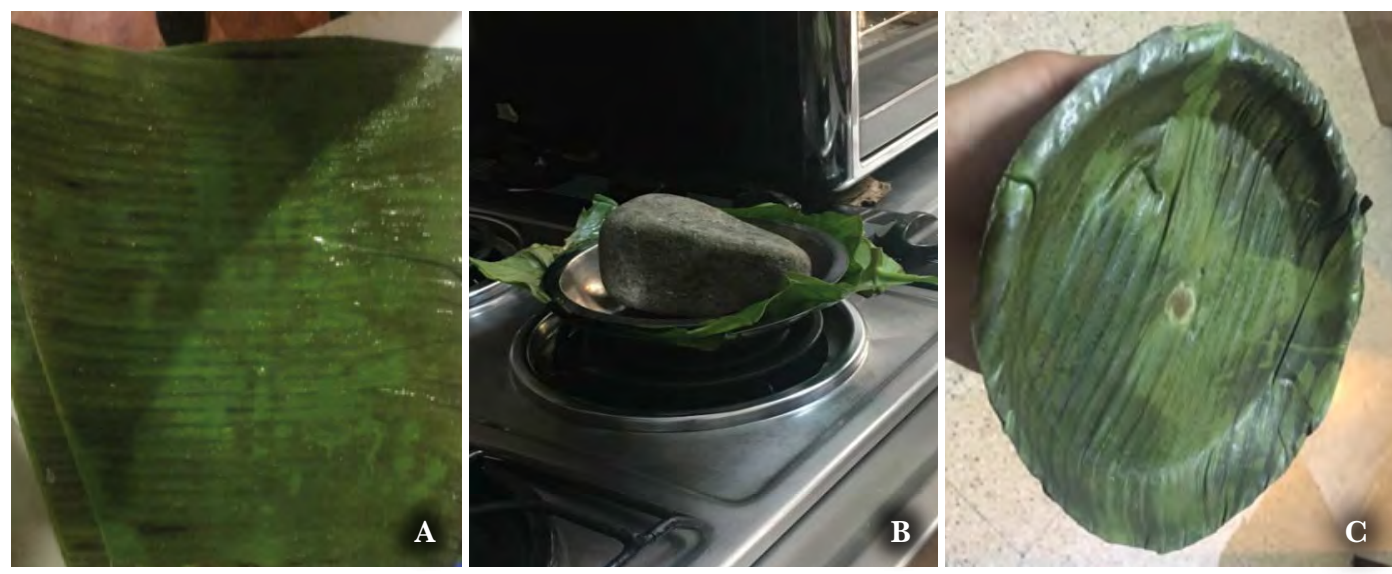

Figure 4. Process of manufacturing a biodegradable dish made from plantain (Musa spp.) leaves and starch extracted from cassava or tapioca (Manihot esculenta). 4A) Leaf covered with starch extracted from cassava or tapioca (Manihot esculenta); 4B) Molded leaf; 4C) Final product taking the form of a dish, useful for serving local foods.

participated as speaker and presented the topic of the elaboration of biodegradable utensils made from banana leaves and cassava starch.

Once the presentation was over, people interested in the project approached to propose a class-workshop to discuss the benefits of creating biodegradable products that reduce the emission of polluting waste, with the intention of creating sustainable tourism in the community of San Rafael. The workshops were held on October 16 and 17, 2019. The first day the workshop was held in a rural school called "Bosqueschool Cariba" in the municipality of San Carlos, in the same Department of Antioquia (Figure 5A), and the second workshop was held in the municipality of San Rafael (Figure 5B).

Back in Mexico, the same initiative was implemented in Monte Salas. Biodegradable plates were made for a festival, and they served as replacement for disposable plastic or styrofoam materials (Figure 6A). In such biodegradable plates, food was served (Figure 6B) previously taking the sanitation measures, which included the perfect cleaning of the leaf
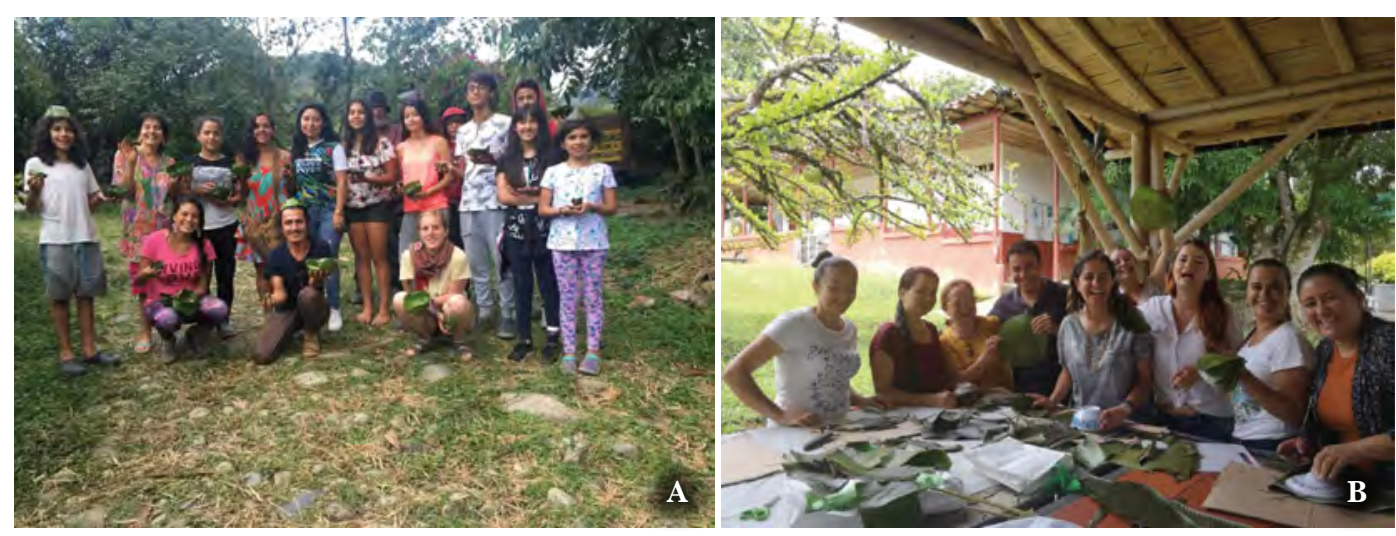

Figure 5. Workshops organized to demosntrate the techniques of elabotation of biodegradable plated from plantain (Musa spp.) leaves and cassava (Manihot esculenta) starch. A) Bosqueschool Cariba, San Carlos, Antioquia, Colombia; B) Association of the Local Tourism Network, San Rafael, Antioquia, Colombia. 

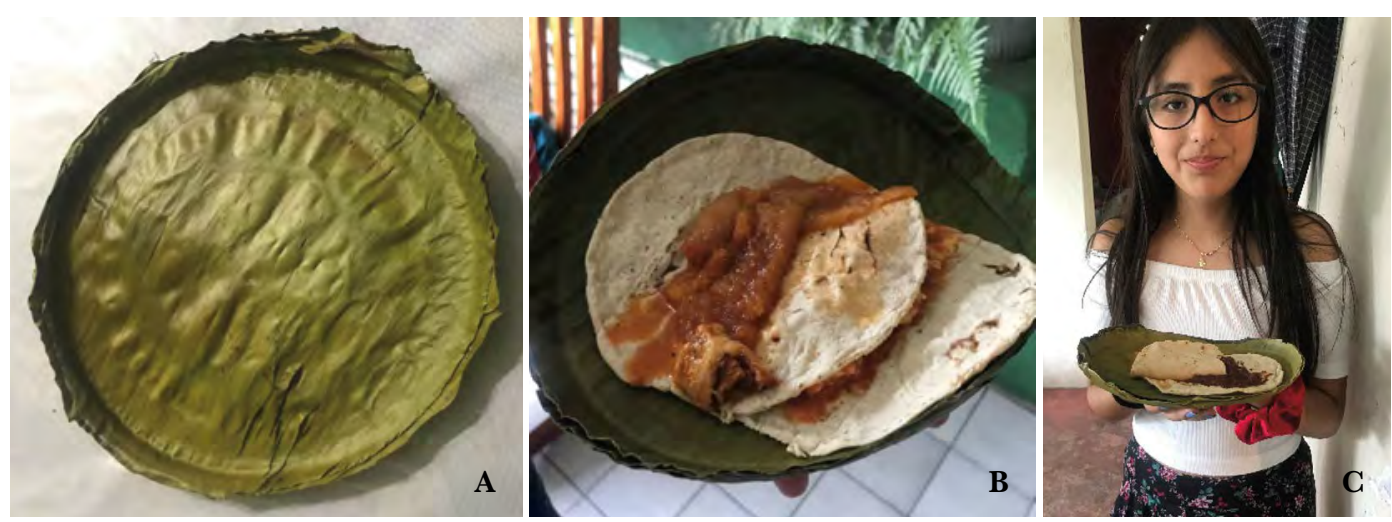

Figure 6. Public demonstration of the biodegradable plates made from plantain (Musa spp.) leaves and cassava (Manihot esculenta) starch in Monte Salas, municipality of Fortín de las Flores, Veracruz, Mexico. A) Prototype of the biodegradable plate; B) Local foods served in the plates; C) People from Monte Salas, consuming local foods served in the biodegradable plates.

to later proceed to the elaboration of the biodegradable plates. The event was attended by people from the town of Monte Salas, who were served in these prototypes that tested their resistance to solid food.

This strategy is serving local dishes as a tourist attraction for people interested in banana cultivation, as well as in the production of biodegradable products based on the banana or plantain leaf.

\section{GONGLUSIONS}

Through this project it was possible to record and analyze the banana production activity in the community of Monte Salas, Fortín de las Flores, Veracruz, Mexico, as well as to offer sustainable alternatives that diversify the income of the producers and in turn attract interested tourists. The alternative use of banana leaves in the production of biodegradable dishes offers the possibility of obtaining extraordinary income, is a sustainable strategy, and can function as a tourist attraction for the community that offers a natural and agroecological landscape of interest.

\section{REFERENGES}

Atlasbig. (2021). Los principales países productores de banano del mundo. Disponible en:https://www.atlasbig. com/es-mx/paises-por-produccion-bananera

CEIEG. (Comité Estatal de Información EstadÍstica y GeogrÁfica de Veracruz). (2020) Cuadernillos Municipales. Disponible en: http://ceieg.veracruz.gob.mx/wp-content/uploads/sites/21/2020/12/ Fort\%C3\%ADn_2020.pdf

Chávez-Hita, A.N., Florescano, E. (2013). Historia general de Córdoba y su región. la ed. Gobierno del Estado de Veracruz. Secretaría de Educación del Estado de Veracruz, Universidad Veracruzana. Mexico.

Cobana, M., Antezana, R. (2007). Proceso de extracción de almidón de yuca por vía seca. Revista Boliviana de Química, 24: 77-83.

Díaz-Arango, F. O., L. León A., Mejia, L.F. G. (2015). Diseño de productos a partir de los residuos de cosecha y poscosecha del plátano Dominico Hartón (Musa AAB Simmonds). Vector, 8: 13-19.

FAO (Organización de las Naciones Unidas para la Alimentación y la Agricultura). FAO Stats. Bananos, plátanos y otros. Disponible en: http://www.fao.org/faostat/es/\#data/QC.

Forman, R. T. T., Godron, M. (2009). Components Ecology Landscape Structural. BioScience, 31: 733-740.

Hiernaux, D., A. Lindón. (2006). Tratado de Geografía Humana. la ed. Anthropos Editorial. Iztapalapa, México. 
Licona V., A.L. (2007). El papel de la clasificación local de tierras en la generación y tranferencia de tecnología: El caso del policultivo café-platano para velillo-sombra en Veracruz, México. Tesis de Doctorado en Ciencias. Colegio de Postgraduados Campus Montecillo.

Mazzeo M., M., L. León A., L.F. Mejía G., L.E. Guerrero M., J.D. Botero L. (2010). Aprovechamiento industrial de residuos de cosecha y poscosecha del plátano en el departamento de Caldas. Asociación Colombiana de Facultades de Ingenieria, 9: 128-139.

Minagricultura (Ministerio de Agricultura y Desarrollo Rural de Colombia). (2020). Cadena de plánano. Disponible en: https://sioc.minagricultura.gov.co/Platano/Documentos/2020-03-31\%20Cifras\%20 Sectoriales.pdf

Pilcher, J. M. (2001). ¡Vivan los tamales! La comida y la construcción de la identidad mexicana. la ed. Editorial Ediciones de la Reina Roja. Ciudad de México.

Ramírez V., B.R., L. López L. (2015). Espacio, paisaje, región territorio y lugar: la diversidad en el pensamiento contemporáneo. la ed. Universidad Nacional Autónoma de México. Ciudad de México.

Villalobos-Arámbula, V.M. (2019). México, potencia agroalimentaria que realiza acciones para un campo con equidad, inclusión y sustentabilidad. Disponible en: https://www.gob.mx/agricultura/jalisco/articulos/

Secretaría de Agricultura y Desarrollo Rural. (2020). Plátano: la fruta tropical más cultivada en México. Disponible en:https://www.gob.mx/agricultura/articulos/hoy-dia-del-platano?idiom=es

Susan T., P.V., J.C. Noa G., N. Flores E. (2017). Estado del Cultivo de Plátano (Musa sp) en el Municipio de Tlapacoyan, Veracruz. Notas Breves, 4: 81-83. Doi: 10.25009/uvserva.v0i4.2550

Thiébaut, V. (2017). Una metodología cualitativa para la lectura y el análisis de los paisajes en México. In: M. Pere S. y M. M. Checa A. (Coords). El Paisaje: reflexiones y métodos de análisis. la ed. Ediciones del Lirio. Ciudad de México.

Troll, G. (2003). Ecología del paisaje. Gaceta Ecológica, 68: 71-84.

Vila S., J., D. Varga L., A. Llausàs P., A. Ribas P. (2006). Conceptos y métodos fundamentales en ecología del paisaje (landscape ecology). Documents d'Anàlisi Geogràfica, 48: 151-166. 